\title{
The persistent myth of crustal growth
}

\author{
R. L. ARMSTRONG* \\ Department of Geological Sciences, University of British Columbia, Vancouver, BC, Canada, V6T $2 B 4$.
}

\begin{abstract}
From the extraterrestrial telescopic, space probe, meteorite and returned sample studies of planetary evolution, and terrestrial evidence for early differentiation of core and fluid spheres and continental crust, I feel the conclusion is inescapable that large terrestrial planets of our solar system underwent essentially immediate differentiation into relatively constant-volume core, depleted mantle, enriched crust and fluid reservoirs. Differentiation was an early event, carried rapidly to completion. It is a false premise to have the formation of sialic crust on Earth dragged out over billions of years after hot accretion. The uniqueness of the Earth arises from its size, retention of water and dynamic surface-renewal processes, which have effectively erased all vestiges of the first several hundred million years of its crustal history. A large volume of depleted mantle always existed and an isotopically nearly homogeneous character for mantle and crust in early times was only sustained by rapid convective stirring of the silicate Earth. The sigmoidal continental crust age curve that is recorded in whole rock $\mathrm{Nd}$ and zircon $\mathrm{U}-\mathrm{Pb}$ dates is a predictable consequence of the highly exponential decline in stirring rates. It represents survival, not the original extent of crustal domains. Positive $\varepsilon_{\mathrm{Nd}}(\mathrm{T})$ values for Archaean mantle-derived magmas are quantitatively predicted by this model, as are the observed depleted-mantle model ages of clastic sedimentary rocks. Current rates of crustal accretion and loss of crust by sediment subduction and tectonic erosion are approximately in balance and compatible with negligible crustal growth at present. Claims that current growth is approximately $1 \mathrm{~km}^{3}$ per year are based on incorrect and selectively cited data and incomplete analyses of the freeboard argument.

The idea that the Earth's crust has grown is a myth dating from the 19th century and was established as geochemical dogma in the 1950s and 1960s. It has survived by inertia and repetition and endless self-citation. The alternative no-growth view has been sometimes ignored, frequently questioned and downplayed, often cited only as an end member hypothesis (on the presumption that the truth must lie between extremes), and sometimes acclaimed and supported. Evidence in its favour has been accumulating. The growth myth has survived, however, as the consensus.

In science, conventional wisdom is difficult to overturn. After more than 20 years some implications of plate tectonics have yet to be fully appreciated by isotope geochemists who advocate crustal growth, and by geologists and geophysicsts who have followed their lead.
\end{abstract}

Key words: crustal growth, freeboard, Nd and Hf isotopes, recycling.

\section{INTRODUCTION: MYTHS AND THE DEFENCE OF CONVENTIONAL WISDOM}

A myth is an invented tale, often to explain some natural phenomenon. In this paper it is argued that the idea of continental crust growth is such a myth, with currency among geochemists, that it has acquired the status of dogma, but that it is without a sound logical foundation. The logical basis that did exist was extinguished with the acceptance of the ideas of plate tectonics, about 25 years ago. Nevertheless the idea of continental growth persists and has been vehemently defended by many champions. It is a dogma that has distorted thinking about the Earth for decades. In science this is an old story, likely to be repeated again, as the defenders of common wisdom are seldom treated with the same scepticism as the challengers of the status quo. The viewpoint advocated here is certainly a minority position. This paper is polemical because it questions the logic of advocates for crustal growth. Crustal growth has been defended with false assertions, defective data, misconceptions and misunderstandings, and with straw-man arguments. The justification given for adopting the crustal growth model in many papers boils down to a statement of belief, an opinion, rather than a deduction from observations. The idea of a continental-volume steady-state, the early attainment of a differentiated Earth, is often acknowledged as an end-member hypothesis, but usually dismissed as less likely than growth, and is sometimes given the ultimate insult of being ignored entirely in discussions of crustal-mantle evolution.

This paper will briefly review the origins of the idea of crustal growth, examine in detail how it has been defended by its strongest, most respected and most cited advocates, and show that the continental-volume steady-state model, with a diminishing crust-mantle recycling rate, predicts observation of $\mathrm{Nd}$ isotope studies that have been claimed to be contrary to the continental volume

\footnotetext{
*R.L. Armstrong passed away 9 August 1991.
} 
steady-state model, and for which contrived and unnecessary explanations have been offered. Short of the invention of time machines, it is difficult to prove that any inference of Earth history from observation of the Earth today is true. But at least the debate should be a fair one.

\section{CLASSICAL GEOCHEMISTRY}

The idea that the Earth's crust has grown through geologic time has venerable antecedents. Walcott (1894) stated:

\begin{abstract}
Since Algonkian time the growth of the continent has been by the deposition of sediments in the bordering oceans and the interior seas and lakes within the limits of the continental plateau: and it is considered that the relative position of the continental plateau and the deep sea have not materially changed during that period.
\end{abstract}

He may have been wrong on both accounts!

In the 1950s geochemists were taught that the crust of the Earth was steadily growing and many arguments and lines of evidence were marshalled in support of this view. It became the premise on which all geochemical evolution models were constructed. Papers by Rubey $(1951,1955)$ were very influential. He argued that both seawater and the continental crust had grown gradually through geologic time. There was little dissent among geochemists. Urey (1954) concluded, 'It seems to the writer that the Earth is differentiating its substance at the present time and has been doing so continuously throughout geologic time'. At that time the chemical and physical nature of the mantle were obscure, and plate tectonics had not entered North American thinking. Continental drift ideas had no impact on geochemical ideas. Internal convection was simply not discussed. The extreme expression of that mind set of fixism and continental growth were models of radial, one way differentiation that received acclaim (e.g. MacDonald 1961).

Standard textbooks helped promulgate the dogma. For example, Krauskopf (1967): 'We shall ... summarize by saying that several lines of evidence suggest strongly that differentiation of crustal rocks out of mantle material is still going on'.

Dramatic development of planetary, meteorite and lunar science in the 1960 s contributed to the demise of the ideas of cold accretion and gradual heating as hard evidence pointed to rapid accretion, early formation of large bodies, and early melting and differentiation. But the idea of early differentiation was vigorously avoided for the solid earth by many geochemists. Only the volatile sphere and core were allowed to form in the first moments of Earth history; the continents had to wait.

The literature was not lacking in alternative viewpoints. Some European geochemists expressed the view that the Earth was in a steady-state, with endless recycling of continental material (Barth 1962, 1968; Nieuwenkamp 1968) and some geologists argued for the importance of recycling (Gilluly 1955) but it was generally argued that $\mathrm{Sr}$ isotopes relegated such a process to a minor role (Hurley et al. 1962). A contrary view was expressed by plumbologists. Alpher and Herman (1951) argued for $\mathrm{Pb}$ evolution in a recycling crust on a differentiated earth, to give the apparent single stage growth of ore lead isotopes. Patterson (1964) argued for a two stage differentiation, from lead isotope data - one early differentiation to form core and protocrust and then a growth of the continental crust from the protocrust (whatever that meant in real-world terms).

Prior to 1968 no geochemists' models of the Earth recognized any feedback from crust into the mantle. It was in this intellectual environment that the dogma of growth became entrenched.

\section{THE ONGOING CONTRADICTIONS}

How can the Earth be rapidly differentiated with respect to core (Solomon 1980) and volatiles (Fanale 1971), yet remain undifferentiated with respect to silicates? That is one contradiction the crustal growth advocates must confront, but usually evade. O'Nions et al. (1979) noticed this contrast but didn't blink, and continued to argue for crustal growth on Earth. Most discussions of volatiles agree on an early degassing of the Earth (Walker 1977; Cogley \& Henderson-Sellers 1984; Allègre 1987; Azbel \& Tolstikhin 1990). Michael (1988) has shown that in ocean ridge magmatism, water is more compatible than $\mathrm{K}, \mathrm{Rb}, \mathrm{Nb}$ and $\mathrm{Cl}$ but less compatible than $\mathrm{Sm}, \mathrm{Zr}$ and $\mathrm{Ti}$. It is just another incompatible component, not independent of other elements that make up the crust and fluid spheres of the Earth. It is illogical to argue that the crust did not fractionate at the same time as the volatiles, but that is what crust growth advocates must do.

So many other solar system bodies differentiated soon after accretion, or even during accretion (Solomon 1980; Smith 1981, 1982), that it seems perverse of the Earth not to do so as well. Patchett (1983) noticed this 'contrast' in planetary evolutions but did not waver from his advocacy of crustal growth. Some planetologists have adopted the steady-state model with conviction. Warren (1989) vigorously attacked the logic of slow growth models from a planetary perspective. His excellent 
arguments will not be repeated here. Morgan (1989) is in substantial agreement. McGovern and Schubert (1989) explained how the Earth can rapidly reach a steady-state with respect to volatiles and internal convection, but they tenaciously adhered to the crustal growth idea of Reymer and Schubert (1984).

\section{ALTERNATIVE VIEW FOR THE EARTH}

Evidence from cosmochemistry of early differentiation of several bodies in the solar system, and from continental freeboard, spurred re-exhumation of the continental-volume steady-state idea. Plate tectonics provided the mechanism for crust-mantle chemical exchange that made such a class of models, with steady-state volumes but declining crust-mantle recycling rate, viable. The model was presented, and embellished, and defended in a series of papers (Armstrong 1968, 1971, 1981; Armstrong \& Hein 1973; Armstrong vs DePaolo 1981).

\section{RARE ACCLAIM}

The response to the idea was generally slow and conservative. In fact the original manuscript (Armstrong 1968) was rejected by reviewers, but then saved by the intervention of P. M. Hurley. A few generalists (Burke et al. 1976; Fyfe 1976, 1978, 1981; Hargraves 1981) and planetologists (Lowman 1976; Smith 1981, 1982) enthusiastically endorsed the proposal. Windley (1977) seemed favourable, but later recanted. Much of the flavour of the steady-state, recycling model was taken up by Stacey and Kramers (1975) and into the Plumbotectonics model of Zartman and Doe (1981), which have been influential in lead isotope interpretations. Far more numerous were objections to the idea that sediment subduction could be important, or doubts that recycling was of major significance (O'Nions et al. 1979; Allègre 1980). A few years later, Allègre (1988 translation of 1983 book) was to claim 'in the late 1960s I began to think ... [about crust-mantle mixing] ... for ten years my explanation convinced no one'. More recently (1987, 1989) he has fairly acknowledged that the idea of recycling was not originally his, and at the International Conference on Geochronology, Cosmochronology, and Isotope Geology in Canberra in 1990 openly acknowledged the steadystate with respect to continental crust volume as a viable and perhaps correct idea to explain $\mathrm{Nd}$ isotope data for ancient rocks (Allègre 1990). Some ignored recycling 'for simplicity' (Jacobsen \&
Wasserburg 1979). Some gave consideration to the idea but did not favour it (DePaolo \& Wasserburg 1979). Later DePaolo (1981a, 1983, 1988) came cautiously on board, and he has supported recycling models much like that of Armstrong (1968, 1981). Kay (1985), and Kay and Kay (1989) were cautiously positive, and have contributed important ideas and observations to the recycling discussion in a number of papers.

\section{OBJECTIONS TO SUBDUCTION OF SEDIMENTS}

It is probably an understatement to say that the idea of sediment subduction, as an important geochemical flux, met with some scepticism, and that this scepticism persisted. Moorbath expressed his opposition early: 'It seems, in any case, rather unlikely that relatively low-density, continental crust can be buried or subducted sufficiently deeply for really massive reworking of the type envisaged by many geologists' (1976) and repeatedly (1977a, b, 1978, 1982). O'Nions and Hamilton (1981) and Condie $(1986,1989 a, b)$ expressed similar doubts. Arculus (1981) felt that evidence for sediment subduction was at best ambiguous, and essentially rejected the idea. Stern and Ito (1983) argued against any subducted sediment component in Mariana volcanic rocks. Tarling (1978) felt that density contrast makes it highly unlikely that sediments are subducted. Weaver and Tarney (1982) declared that 'massive sediment subduction into the mantle throughout geological time ... appears unlikely'. McCulloch (1987) states that 'massive recycling of continental crust ... is an unlikely scenario'. This is just a sampling of the negative opinions expressed over the past 20 years.

\section{ARGUMENTS FOR AND AGAINST THE SUBDUCTION OF SEDIMENTS}

McLennan (1988) and White (1989) have provided excellent reviews of the topic of sediment subduction and crust-mantle recycling. Only the major points need to be listed here. The most persuasive evidence for sediment subduction is $\mathrm{Pb}$ isotope composition of and ${ }^{10} \mathrm{Be}$ presence in volcanic arc rocks. Many other elements are consistent with a $2-5 \%$ component of sediment in arc igneous rocks.

Only two significant trace element and isotope arguments have been raised against sediment subduction. The first is constancy of $\mathrm{Nb} / \mathrm{U}$ and $\mathrm{Pb} / \mathrm{Ce}$ ratios in MORB and OIB (Hofmann et al. 
1986). But several authors recognized that this may be due to decoupling of element behaviour in complicated fluid transfer, melting and mixing processes occurring in the mantle beneath subduction zones (Ben Othman et al. 1989; White 1989; Hart \& Staudigel 1989) and is thus not disproof of sediment subduction.

The second argument is the $\mathrm{Hf}-\mathrm{Nd}$ correlation in volcanic rocks (Patchett et al. 1984). This will not be as observed unless a mixture of approximately equal amounts of turbidite and pelagic sediment are subducted and reasonably well mixed. This argument does rule out recycling of pelagic sediment only but that is a straw-man, not the process advocated for the steady-state, which envisages a large component of terrigenous material in the subducted flux of material. Even on the ocean floor, away from continental margins, the sediment mix is about right to fit the isotope correlation observed. Sujkowski (1952) estimated that sediment on the ocean floor is $52.9 \%$ pelagic, $47.1 \%$ terrigenous. Taylor and McLennan (1985) used a conventional figure of $60 \%$ for the terrigenous component. If this is the material being subducted then the $\mathrm{Hf}-\mathrm{Nd}$ array is in no way an argument against sediment subduction. Patchett et al. (1984) went on to speculate that 'pelagic sediments and turbidites may be subducted at different sites' and this should produce more scatter than is observed. But this is hardly a persuasive argument. One might respond: trenches and where else? Patchett et al. (1984) were left with the objection that more sediment must be subducted than they believed possible, but had no observational basis for this position. The amount of sediment required to produce the shift in Hf isotopes from depleted mantle to arc values is about $1-2 \%$ of the volcanic flux. This is consistent with the amount of other sediment components observed in volcanic arc igneous rocks.

Evidence for sediment subduction in Archaean igneous rocks is of the same nature as that for modern igneous rocks (except that ${ }^{10} \mathrm{Be}$ is not applicable because of its short half life; Mueller \& Wooden 1988, 1989).

It is now recognized that the subduction of sediment and associated volatiles is a major control on the oxidation state of the upper mantle (Mattioli et al. 1989).

\section{UNDERESTIMATING THE IMPORTANCE OF SEDIMENT SUBDUCTION}

A number of authors have concluded that sediment subduction was only of minor importance because only a few per cent of recycled isotope and chemical components such as $\mathrm{Pb}, \mathrm{K}, \mathrm{Cs},{ }^{87} \mathrm{Sr}$ and ${ }^{10} \mathrm{Be}$ can be identified in arc magma. The presence and abundance levels are not in dispute. The implications to be drawn are very different. Examples of such rejection are Oversby and Ewart (1972), Church (1973), Karig and Kay (1981), Stern and Ito (1983), Wolery and Sleep (1988) and Howell (1989).

The fallacy here is due to failure to appreciate the effectiveness of the mantle as a buffer that masks most of the sediment contribution. For that few per cent of sediment to show up in the magmas erupted, much larger volumes of mantle must be equally as contaminated with a sediment component. It is not unreasonable to infer that the mantle to magma ratio might be 20-50 to 1 (this is entirely consistent with O'Nions's (1990) and McKenzie and O'Nions's (1990) estimates of melt fractions in the order of $1 \%$ in arc magma genesis to explain crust-mantle trace element fractionation patterns) and the flux of subducted sediment fully as large as the volcanic flux. This point was made in the original proposals of the steady-state model (Armstrong 1968) and has been understood by many who have discussed the evidence (Ellam \& Hawkesworth 1988; Ben Othman et al. 1989; Hawkesworth \& Ellam 1989; Neal \& Taylor 1989).

\section{THE ${ }^{208}$ Pb PARADOX}

The ${ }^{208} \mathrm{~Pb}$ paradox (more ${ }^{208} \mathrm{~Pb}$ in oceanic volcanic rocks than could be explained by the $\mathrm{Th} / \mathrm{U}$ ratio of the volcanic source region) was rediscovered by Galer and O'Nions (1985) although the point had already been made by Armstrong (1968). This is analogous to the observation of deficiencies of ${ }^{143} \mathrm{Nd}$ and ${ }^{176} \mathrm{Hf}$ in mantle-derived volcanic rocks discussed by DePaolo (1983). All these paradoxes are explicable by sediment subduction. The extremely high 'sialic affinity' of Th (Allègre \& Lewin 1989) results in the continental crust being the principal terrestrial site of ${ }^{208} \mathrm{~Pb}$ generation on Earth. To invoke a deep mantle source for the excess ${ }^{208} \mathrm{~Pb}$ is illogical. It could only be done because Galer and O'Nions (1985) rejected sediment subduction out of hand. Zartman and Haines (1988) raised further objections to the rejection of crustal recycling by Galer and O'Nions (1985).

\section{EVOLUTION MODELS IN THE 1970s AND 1980s}

Since 1968 most geochemists have adhered to a model of continent crust growth that is sigmoidal in 
shape, starting at zero more recently than $4.0 \mathrm{Ga}$, rising steeply between 3.4 and $1.7 \mathrm{Ga}$, and then rising gradually to the present. This is the position taken by Veizer (1976), Allègre (1980, 1982, 1987), McCulloch (1987), Jacobsen (1988), and Condie $(1989 a, b)$. In more than one discussion the sigmoidal growth model has been chosen simply because it is a compromise between the extremes (e.g. Veizer 1976).

DePaolo (1980) concluded that crustal growth with a constant recycling rate does not work for Nd isotope observations but later (1981a) admitted that a constant-volume, declining recycling rate model can be accommodated by the observations. Albarède and Brouxel (1987) agreed. Patchett and Chauvel (1984) argued that undepleted mantle rather than continental crust might supply the unradiogenic $\mathrm{Nd}$ needed to explain retarded growth of radiogenic $\mathrm{Nd}$ in depleted mantle as observed by DePaolo (1983). But that proposal presupposes a major rather than minor OIB reservoir in the mantle, and is unnecessary.

In general the idea that crust-mantle recycling does occur has been widely adopted, but affection for the crustal growth model has hardly diminished (McLennan 1988).

\section{FLUXES OF MATERIAL: A REFUTATION OF REYMER AND SCHUBERT (1984) AND MANY OTHERS}

One of the most often cited arguments for continent crust growth is presented in the papers of Reymer and Schubert $(1984,1987)$ and Schubert and Reymer (1985). They presented two independent, and apparently supportive, arguments for growth at the rate of about $1 \mathrm{~km}^{3}$ per year. Critical examination shows both their arguments to be without foundation.

\section{Apparent crustal growth rates}

The greater part of Reymer and Schubert's discussion is a careful accounting for all the components of crustal growth: accretion of arcs, marginal basins, ophiolites etc., leading to a figure of $1.65 \mathrm{~km}^{3}$ per year for Phanerozoic time. This is material that can be observed and is not a particularly controversial or new conclusion. Nieuwenkamp estimated $1.5 \mathrm{~km}^{3}$ per year in 1968; Francis and Rundle estimated somewhat more than $1 \mathrm{~km}^{3}$ per year in 1976; Dewey and Windley (1981) estimated a minimum of $0.6 \mathrm{~km}^{3}$ per year, derived from an argument much like that of Reymer and
Schubert. There is a notable discrepancy between these figures and numbers calculated by volcanologists for average rates of magma production. Schmincke (1981) gives $2.1 \mathrm{~km}^{3}$ per year for destructive margins; Crisp (1984) estimated 2.9 to $8.6 \mathrm{~km}^{3}$ per year. An additional, but unqualified, flux may be involved in 'underplating' (Voshage $e t$ al. 1990) in orogenic areas. These larger estimates require a large flux of recycled destructive margin volcanic or volcaniclastic material into the mantle in order to maintain the observed mass balances. This may not be impossible. It would be almost invisible from an isotopic standpoint. Long-term rates of crust addition, based on the crust age distribution curve (most recently evaluated by Condie 1990), give a similar apparent net accumulation rate of $1 \mathrm{~km}^{3}$ per year. That figure is solidly based and relatively non-controversial.

\section{Sediment flux}

Dewey and Windley (1981) reviewed crustal growth and gave a total pelagic sediment flux of $0.81 \mathrm{~km}^{3}$ per year, a net pelagic subduction flux of $0.63 \mathrm{~km}^{3}$ per year (for subcretion and digestion into the mantle) and tectonic erosion flux of $0.17 \mathrm{~km}^{3}$ per year, with little explanation of how these quantities were obtained. Both, it turns out, are gross underestimates of reality, yet these have been taken as cornerstones of the argument for continental growth by many later authors, including Reymer and Schubert. The estimate of $0.81 \mathrm{~km}^{3}$ per year for the pelagic flux is questionable. Given a MesozoicCenozoic sea floor generation rate of $3.0 \mathrm{~km}^{3}$ per year (Parsons 1981), this implies an average compacted sediment thickness of only $270 \mathrm{~m}$ on the ocean floor. The average 'man on the street' could recognize that this is low by at least a factor of 2 .

Karig and Kay (1981), in the same symposium, estimated a total pelagic sediment flux into convergent margins of $1.6 \mathrm{~km}^{3}$ per year, but stated that the "overwhelming proportion of trench sediment and large portion of pelagic' sediment were not deeply subducted, and that tectonic erosion was 'relatively minor'. They calculated that only $0.15 \mathrm{~km}^{3}$ per year of sediment was needed to provide the potassium in volcanic rocks of destructive margins. But this has to be much less than an absolute minimum for the subduction flux. Several times as much are needed to contaminate the mantle associated with magma genesis.

Reymer and Schubert $(1984,1987)$ and Schubert and Reymer (1985) incorrectly took the average of Dewey and Windley's pelagic subduction flux (itself 
a gross underestimate) and Karig and Kay's minimum flux (which has to be several times too small) to obtain their total sediment flux available for subduction $(0.63+0.15) / 2$ equals approximately $0.4 \mathrm{~km}^{3}$ per year). Other authors have cited this low figure as an established fact (e.g. Condie 1989a, b). In doing so these authors chose to ignore other vast quantities of sediment that are vulnerable to subduction, thus strongly biasing their arguments in favour of continental growth.

\section{Potential recycling flux}

Several papers have evaluated the volume of pelagic sediment (all converted to an average crustal density of $2.75 \mathrm{~g} / \mathrm{cm}^{3}$ ). Poldervaart (1955) estimated $80 \times 10^{6} \mathrm{~km}^{3}$. Gregor (1985) gave $79 \times 10^{6} \mathrm{~km}^{3}$. Howell and Murray (1986) sum up $55 \times 10^{6} \mathrm{~km}^{3}$, excluding continental rises, the Arctic Ocean and near Antarctic regions. Hay et al. (1988) gave $95 \times 10^{6} \mathrm{~km}^{3}$ total sediment on the ocean floor. Mass-age distribution curves are exponential so that the steady state accumulation rate implied by these figures is about $1.9 \pm 0.2 \mathrm{~km}^{3}$ per year, or about a quarter of the global sediment flux into the oceans. Unless the mass of sediment on the ocean floor is increasing or decreasing this is then the average flux of pelagic material available for subduction. Estimates of Cenozoic sedimentation rates (e.g. Davies et al. 1977) give a similar figure, about $2.4 \pm 1.2 \mathrm{~km}^{3}$ per year at 2.75 $\mathrm{g} / \mathrm{cm}^{3}$. At $2.0 \mathrm{~km}^{3}$ per year the entire mass of the continents would be recycled in $3600 \mathrm{Ma}$. Given that fact it defies logic to use crust age distribution curves as equivalent to crust growth curves, as is sometimes done.

Most authors agree that a large fraction of the pelagic accumulation is subducted, but even if only half (and that is even less than the percentage estimated by Dewey and Windley (1981) and Reymer and Schubert (1984)) is subducted the actual amount is more than twice as great as the figure used in their papers (and cited by others) for the total deeply-subducted sediment flux.

Tectonic erosion, 'decretion' of Dewey and Windley (1981), has been difficult to quantify and often given short shrift. Reymer and Schubert (1984 and sequels; McLennan 1988) used the $0.17 \mathrm{~km}^{3}$ per year figure of Dewey and Windley (1981), without significant modification. Meanwhile there has been a growing literature on convergent margin studies. that observe sediment subduction and tectonic erosion at much larger rates than implied by the numbers used by Reymer and Schubert (1984).
Scholl (1974) and Scholl and Marlow (1974) observed 1-2 $\mathrm{km}$ of hemiterrigenous sediment overlying $200-400 \mathrm{~m}$ of pelagic sediment on the plate being subducted in North Pacific trenches (more than just pelagic sediment is carried into trenches), and most of that sediment was being subducted rather than accumulating in an accretion wedge. Likewise, sediment subduction and tectonic erosion were observed as dominant over accretion in Central America (Aubouin et al. 1981), in the Marianas (Hussong \& Uyeda 1981; Bloomer 1983), Japan Trench (Langseth et al. 1981) and South America (von Huene et al. 1985; Stern 1989). All these observations run counter to the antisubduction attitude expressed by Karig and Kay (1981) and imply a much more significant role for tectonic erosion than the small amount advocated by Dewey and Windley (1981).

From an entirely independent evaluation of convergent margin fluxes, based on deep sea drilling, palaeo water depth and seismic data, Scholl et al. (1990) estimated that the volume of sediment being recycled by subduction is about $0.7 \mathrm{~km}^{3}$ per year. Their figure for concurrent tectonic erosion is less precise but comparable, $1.1 \mathrm{~km}^{3}$ per year. The total observed deep-subduction flux (minimally 1.3-1.8 $\mathrm{km}^{3}$ per year), derived from, the most precise cross-sections of continental margins that can now be constructed, is about equal to the recorded rate of addition of material to the continental crust.

To add further insult to the argument the authors who are cited as favouring continental growth all chose to ignore other potentially subducted material. No allowance was made for sediment of continent margins or trench fill, which might increase the potential sediment available by a factor of two or more. The $0.6 \mathrm{~km}^{3}$ per year of material allowed by Reymer and Schubert (1984) for subduction ignores ocean islands, oceanic arcs and ocean plateaus as additional potentially subductable material.

One can only conclude that papers such as Reymer and Schubert (1984), Dewey and Windley (1984) and Karig and Kay (1981) are fundamentally biased against the idea of steady-state continents. Numbers have been picked and modified in total disregard of well-known facts. Yet because these papers are defenders of common knowledge these assertions have gone unchallenged.

An important new element of the discussion, and one that gives even more opportunity for crustmantle exchange and chemical fractionation, is the idea that lower crust in volcanic arc regions may be delaminated and lost from the crustal reservoir (Kay 1985; Kay \& Kay 1989). Dimroth (1985) appears to have come to this same idea independently, 
from different evidence. Others have seized on the idea and its implications (arc root delamination solves the problem of mismatch between average continental crust composition and average volcanic arc magmas, which are more mafic than the average crust; e.g. Arndt \& Goldstein 1989; Pearcy et al. 1990). And one more process is added to the list for creation of mantle enrichment and heterogeneities. Direct observation for such a process is provided by the LITHOPROBE deep seismic profiles of Vancouver Island (Clowes et al. 1987). There, the entire lower crust of the exotic terrane Wrangellia has vanished, presumably into the mantle, and been replaced by Cenozoic ocean crust, volcanoes and sediment, with little disturbance evident at the land surface while this occurred. This is a seismic profile of immense geochemical implication! It is a repudiation for those who disbelieve in sediment subduction and tectonic erosion as processes of major significance.

\section{Freeboard again}

The original freeboard argument of Armstrong (1968) and Wise (1974) was a first order deduction from the qualitative observation that sea level had not greatly deviated from the present base level of erosion through much of geological time. The conclusion reached was that this was possible only if the continental mass was not growing and had not grown for the duration of the geological record during which shallow water sediment had been preserved on stable cratons. The uniformity of continent crust thickness back to at least $3.0 \mathrm{Ga}$ (Condie 1973, reaffirmed in 1989b) supported this view and extended the evidence for a steady-state back in time. The argument that underplating processes could modify this observation is not convincing; it would imply a magmatic process acting with equal effect under continents of all ages at all times.

Reymer and Schubert (Reymer \& Schubert 1984, 1987; Schubert \& Reymer 1985) took the argument one step further (following Dewey \& Windley 1981) in a quantitative model that argued: if freeboard is constant and the ocean ridges have diminished in volume through time (a logical inference given the decay of radiogenic heat sources and present geophysical models of ridge topography and thermal evolution), then there must be growth of continental volume at the rate of about $0.9 \mathrm{~km}^{3}$ per year. In giving attention to one refinement of the argument they ignored others that fully negate their conclusion. This was pointed out in written correspondence in 1983 but they chose to dismiss the issues raised as unimportant. The other refinements are several and significant. Precise conclusions hinge on the ability to infer the ancient structure of ocean and continental lithosphere, and are a bit elusive. The points to be addressed are the secular subsidence of the continents themselves, secular changes in freeboard, thickness of sediment on the ocean floor, and structure of the ocean crust and lithosphere in ancient times.

It is an observation that continental lithosphere thickens with age. Kono and Amano (1978) showed that the change in North American lithosphere thickness going from areas $500 \mathrm{Ma}$ in age to areas $2500 \mathrm{Ma}$ in age is about $40 \mathrm{~km}$. This is an average figure but probably adequate as an order of magnitude estimate for global changes through much of geologic time. The subsidence resulting in this change in thickness is $0.5-0.6 \mathrm{~km} / 10^{9} \mathrm{Ma}$ (using the elevation and lithosphere thickness relationship of Crough \& Thompson 1976 and Condie 1984, respectively). Schubert and Reymer (1985) stated that a $200 \mathrm{~m}$ change in freeboard changes their calculated growth rate by $40 \%$ or that a $400 \mathrm{~m}$ change would cancel their inferred growth. Nisbet (1987) implied a decrease in lithosphere thickness in the order of $200 \mathrm{~km}$ since Archaean time, which would imply subsidence of several kilometres. At face value it appears that lithosphere thickening alone more than cancels the effects of ocean ridge shrinkage that were calculated by Reymer and Schubert.

There is increasing evidence that freeboard is not exactly constant. A secular decline in sea level in the order of hundreds of metres is implied by the observation of Hoffman (1989) that Archaean rocks are preferentially exposed in the North American Precambrian Shield. He states that $84 \%$ of the exposed Precambrian shield is Archaean, or reworked Archaean, whereas substantially less than $50 \%$ of the sediment-covered basement under stable platforms is Archaean. Recent work on basement ages in the Cordilleran region supports that observation: under the geosyncline only about $20 \%$ of the basement is Archaean (Armstrong et al. 1991). While it is difficult to quantify this observation, it implies a secular drop of sea level with respect to ancient cratons, and cancellation of a significant part of the growth inferred by Reymer and Schubert.

If the ocean floor was being generated and consumed much faster in Archaean time, as is a common consensus, then its structure must have been different in several ways. There may have been less sediment, on average, on the ocean crust. If only half as much, if spreading rates were doubled, then sea level would drop about $70 \mathrm{~m}$, further cancelling 
one sixth of the proposed continental growth. All these factors work against the conclusion of Reymer and Schubert that the continental crust must have grown in volume.

A significant uncertainty is the structure of the ancient oceanic crust. Most authors (e.g. Bickle 1986; Nisbet 1987) infer that faster spreading linked to higher mantle temperatures would result in thicker crust, as occurs over present day plumes. The amount of thickening is somewhat dependent on petrologic models and thus not easily quantifiable. A $200^{\circ} \mathrm{C}$ increase in potential temperature today would increase crustal thickness $20 \mathrm{~km}$ according to McKenzie and Bickle (1988). Hoffman and Ranalli (1988) estimated Archaean ocean crust thickness as $25-50 \mathrm{~km}$. Sleep and Windley (1982) concluded that the Archaean ocean crust would have been greater than $20 \mathrm{~km}$ thick. Nisbet and Fowler (1983) inferred an Archaean crust $15 \mathrm{~km}$ thick, with density 3.25 . Nisbet (1984) preferred a slightly higher figure, $20 \mathrm{~km}$. With an upper mantle density of 3.30 (Condie 1984) or 3.2 (Nisbet 1984), a $20 \mathrm{~km}$ increase in ocean crust thickness would raise or lower sea level by $1 \mathrm{~km}$ ! The density of the Archaean high-magnesium ocean crust and depleted mantle would not be very different and the subtraction of two uncertain numbers creates considerable uncertainty. But the change in 'crust' thickness is largely due to a transfer of olivine from mantle lithosphere to ocean crust, and this should not, in itself, have a great effect on the isostatic position of the seawater volcanic interface.

By now it should be clear that Archaean sea level depends on a number of factors not considered by Reymer and Schubert and is not as easily predictable as their discussion implies. Several of those factors more than cancel the continental growth they calculate. Change in crust structure and in density of crust and underlying mantle between Archaean and modern times add uncertainty, but do rule out the freeboard models of essentially constant or even shrinking continental crust volume through time. Yet Jacobsen (1988), for example, cited Reymer and Schubert (1984) as the reason for not considering steady-state models in his review of crustal growth and recycling models.

\section{VOCAL PROPONENTS OF GROWTH AND THEIR ARGUMENTS}

To underline the point that respected defenders of the crustal growth myth have based their view on a weak foundation it is instructive to review the arguments that several have given for rejecting the continental volume steady-state model.

\section{Jan Veizer}

Jan Veizer has written a number of papers on the topic of recycling in crustal systems $(1973,1976$, 1983, 1988; Veizer \& Jansen 1979, 1985) with many valuable insights. But he is a determined proponent of the sigmoidal growth curve, in spite of generous recognition of the continental-volume steady-state proposal and its implications. He has admitted repeatedly that the crust age-distribution curve and isotope data could be explained by the steady-state but he then gave his reasons for rejecting that model. They boil down to rejection of the process of sediment subduction as a dominant process (he admitted to some sediment subduction but went on to argue that sediment evolution is $95 \%$ cannibalistic, subduction recycling relatively unimportant) and to statements of belief or assumption, and cited his various previous discussions. Veizer (1976) identified the continental crust age-distribution curve as fundamentally due to recycling. He went on to observe the range of explanations to lie between exponential growth without recycling (Hurley \& Rand 1969) and recycling in a continental volume steady-state (Armstrong 1968) and came to favour a compromise solution, growth with recycling, because 'it is likely that the actual situation was somewhere between the two extremes' (p. 36). This is a compromise, more than a scientific decision.

Veizer and Jansen (1985) used the expression 'preferred growth model' in their discussion of crustal evolution and refer back to their earlier (1979) paper. There they referred only to Veizer (1976), the 'preferred' compromise, and Moorbath (1977a) and related papers on the implications of $\mathrm{Sr}$ isotope studies. This amounts to a rejection of sediment subduction as a significant geochemical flux. No further justification is given.

Veizer (1988) emphasized his preference for the logistic growth model: the sigmoidal growth curve. In doing this he implied that crust differentiation should mimic the growth of bacteria in a nutrient medium, an analogy that is not logically convincing. Magmatic fractionation is not a self-catalysing process, inhibited from taking place by a lack of product. At high temperature, equilibrium fractionation is rapidly attained. His statement, 'The reasons for its [the crust's] delayed formation are related to a decrease in the geothermal gradient with the passage of time' (1983, p. 244), is equally bewildering. The logic escapes me. His other reasons for rejecting crust-mantle recycling (Veizer 1988) are that different isotope systems give different mean ages for the continental crust, that only stable basement should survive Archaean 
rapid recycling (there should be no preservation of greenstone belts), and the dearth of old detrital components in Archaean sediments. The first is eloquently countered by Goldstein's (1988) discussion of decoupling of isotope evolutions, the second can be deflected with the response: What if there was no stable basement in the early Archaean, only greenstone and high-grade mobile belts? Something would have to be preserved. The observation would then bear no weight as an objection to recycling. The third matter is taken up later when it is shown that the observed sediment model age curve is exactly that predicted by the steady-state model, with vigorous Archaean recycling. I conclude that Veizer's sigmoidal growth model is a viewpoint, an opinion, an assumption, not a logical deduction from observations, and has to be viewed as such, and not treated like a fact.

\section{K. C. Condie}

Kent Condie is a strong advocate of the sigmoidal growth model for continental crust. He has published many discussions of crustal growth $(1973,1980,1985,1986,1989 a, b, 1990)$, becoming a more adamant growth advocate with time. Discussion can focus on the reasons he gave for that belief in two of his latest and lengthy publications (1989a, b). In rejecting the steady-state he cited Reymer and Schubert (1984) as showing that freeboard constancy implies growth at a rate of about $1 \mathrm{~km}^{3}$ per year. This argument has already been disposed of. He doubted that much sediment could be recycled, especially deep into the mantle, an $a$ priori rejection of sediment subduction. In support of that rejection he cited the small fraction of sediment component, a few per cent, in volcanic arc igneous rocks: a fallacy previously discussed and reputed. He declared that the supply of sediment to the oceans is less than $1 \mathrm{~km}^{3}$ per year and thus inadequate. This is a non-fact, as already explained in the discussion of Reymer and Schubert (1984). The material available for subduction is substantially more than $1 \mathrm{~km}^{3}$ per year, unless Condie wishes to deny the observations of many other scientists. $\mathrm{He}$ asserted that model $\mathrm{Nd}$ ages of sediments show that there was no significant early recycling of continental crust. It will later be shown that the data perfectly well fit the steady-state, recycling model. He admits that positive initial $\varepsilon_{\mathrm{Nd}}$ of Early Archaean igneous rocks 'could present a problem for the Late Archaean rapid growth rate model'. All of Condie's reasons for rejecting the steady-state are without foundation.

His textbook (1989b) is an excellent survey of modern geochemistry and plate tectonics, but his crustal evolution ideas have to be taken with a grain of salt.

\section{S. R. Taylor and S. McLennan}

Ross Taylor has been writing about the growth of continental crust since the 1960 s, when he proposed a radial-differentiation model of continental formation from andesite (Taylor \& White 1965; Taylor 1967). In the 1980 s he was joined by Scott McLennan and together they wrote a series of papers supporting continental growth models. Much of the factual basis of these papers has been chemical analyses, with emphasis on the well documented difference between Archaean and post-Archaean sediment REE and trace element patterns (Taylor 1977 and sequels). In 1979 Taylor cited $\mathrm{Sr}$ and $\mathrm{Nd}$ isotope data as proof of crustal growth, and he has tenaciously held to that belief. McLennan and Taylor (1981) and Taylor and McLennan (1981a) put limits on the sediment component in island arc volcanics on the basis of the absence of a Eu anomaly in arc magmas, limiting the sediment component to less than a few per cent: 'trivial amounts', or at an extreme ' $<10 \%$ '. This is not a serious problem for the recycling models because they are compatible with only a few per cent sediment component in arc volcanic rocks, within the bounds given by Eu data. This fallacy has already been discussed.

Taylor and McLennan (1981b) and McLennan and Taylor (1982) insisted that the change in sediment chemistry between Archaean and later times reflected a major episode of continental growth. They cited Veizer and Jansen (1979) and isotopic evidence for continental growth in support of their views. I have never been able to figure out the logical connection between sediment chemistry and crustal volume. Crustal chemistry could change, as tectonic styles evolve and stable cratons enter the picture, without any necessary change in volume.

McLennan and Taylor $(1982,1983)$ argued that their modest-growth model (only about $20 \%$ since the Archaean) fits freeboard observations and they minimized the amount of sediment available for recycling by citing references favourable to their position. They claim that constant freeboard fits their modest growth model but they have to strain the argument to do so. They admit that the recycling option could be valid if all the available pelagic sediment were subducted. As in other biased discussions they ignore any non-pelagic sediment or tectonic erosion in their discussion. Their book (Taylor \& McLennan 1985) repeats the claim that 
less than $3 \%$ sediment is recycled in volcanic arc magmas several times, repeat their freeboard claim for their post-Archaean modest-growth model, and the argument that change in sediment chemistry about $2.5 \mathrm{Ga}$ ago and $\mathrm{Nd}$ isotopic data require a large increase in continental crust volume. They conclude that less than $1 \mathrm{~km}^{3}$ per year of sediment is available for subduction and of that perhaps less than $0.3 \mathrm{~km}^{3}$ per year is actually subducted, and thus reject the steady-state model. All of their arguments against the steady-state have been disposed of above.

McLennan's excellent review (1988) gave a more balanced view of the evidence and issues, with clarification of many points, but he favoured some growth and some recycling as a 'middle ground'.

\section{THE CRUST AGE-DISTRIBUTION CURVE}

The minimum crustal growth curve that any crust evolution model must accommodate is the observed continental crust age-distribution curve. Hurley and Rand (1969) made the first attempt to quantify this curve but the original compilation was the basis for historically significant crust evolution models (Hurley et al. 1962). Continued geochronometric field work has generally pushed the Hurley and Rand crust age-distribution curve upwards, towards ever larger average crust ages, and towards the sigmoidal shape now common to most growth curves. The curve defined by Nd crustal-residence age (e.g. Nelson \& DePaolo 1985) is probably approaching a true limit, representing the crustal residence age of existing crustal material, a crustal survival curve, not a growth curve. Any amount of crust recycling by deep subduction will shift the true-crustal-volume curve from the highest agedistribution curve towards the steady-state constant value. Perhaps this is why some opponents of sediment subduction are so passionate. The age-distribution curve has already risen to where the maximum growth rate or craton recycling flux for Phanerozoic time is about $1 \mathrm{~km}^{3}$ per year (e.g. Condie 1990). Any concession towards deep subduction of continental material in the order of $1 \mathrm{~km}^{3}$ per year cancels the logical basis for crustal growth in recent times. If, as seems logical for any thermally driven process in the Earth, the recycling rate increased back in time the entire discrepancy between the crust age-distribution curve and the steady-state constant value can be explained, without the necessity to invoke any other process. It should be noted that recycling of young volcanic arc material would be invisible in much of the above discussion. The flux being debated is of approximately average continental crust age.

Wasserburg (1961) realized the importance of the resetting of isotopic clocks in the production of age-distribution curves. He said,

We should thus be cautious about attributing a character of intrinsic stability to shield areas, since this may be more a reflection of the time scale of tectonic events rather than an intrinsic stability of parts of the continents in themselves.

Those who treat age-distribution curves as continental crust volume curves have forgotten his warning.

Gurnis and Davies (1986) have demonstrated how a crust age-distribution curve much like the one observed can logically fall out of a recycling model with exponentially decreasing rates of recycling. Veizer (1976 and later papers) admitted that the age-distribution curve could be the consequence of recycling in a steady-stage, but elected to deny that model on grounds of belief in crustal growth.

Richter (1988) and Peltier (1989) emphasized an important aspect of thermal evolution for all these discussions. Therefore, there will be an early stage of exceptional heat loss, lasting for about a billion years for a planet like Earth, and a later stage of thermal decline following radioactive decay and heat contributed by slow cooling of the interior. The early period will be one of vigorous convection, and it is presumably that rapid convection which is responsible for erasure of the first billion years of the geological record. The point to be drawn from this discussion is that there could have been lots of early crust but none survived, and there is nothing remarkable or unexpected about this. The change of sediment geochemistry, ocean chemistry etc. between the beginning and end of Archaean time is a consequence of the crossing of thresholds where continental crust survival became increasingly more probable. And there would have been significant accompanying changes in tectonic behaviour and petrologic processes. Initially only arcs and microcontinents survived; later large cratons were defined by their survival. Now we have long narrow mobile belts wrapped around composite cratons. The progression described is rather analogous to the idea of closure temperature in geochronometry. Above a certain temperature nothing is retained, there is a temperature interval of partial retention, and a temperature below which retention is total. For the thermal history of the Earth we live in the equivalent of the partial retention stage. The Moon and Mars have reached a cold terminal stage where no tectonic renewal of crust takes place. 


\section{NEODYMIUM INITIAL RATIOS}

Positive $\varepsilon_{\text {Nd }}$ values for mantle-derived Archaean magma, implying a long-term depleted source, have been a puzzle, contradicting any inference of an undifferentiated Earth before 3.0 Ga. Shirey and Hanson (1986) and Smith and Ludden (1989) documented the occurrence of these positive values but expressed doubt that the continental crust can be the complementary enriched reservoir. Windrim and McCulloch (1986) rejected crust recycling (citing Reymer \& Schubert 1984) and advocated mixing of depleted and primitive mantle to explain the ENd growth curve. Chase and Patchett (1988) offer the novel explanation that the large and substantially light rare earth enriched reservoir is ancient ocean crust, stored in the mantle. But no Archaean mafic-ultramafic lavas have the consistently LREE enriched patterns needed to make such a crust (Jahn \& Gruau 1989; Sun 1989). Chase and Patchett (1988) asserted that continental crust could not have been a suitable reservoir, but as shown below this is simply wrong. They did not recognize or understand the quantitative features of the steady-state model, and rejeced it without a fair evaluation. Their alternate explanation is both contrived, requiring an unobserved terrestrial reservoir, and unnecessary.

Positive $\varepsilon_{\mathrm{Nd}}$ values for the average Archaean mantle are predicted by the steady-state, crustal recycling model of Armstrong (1981). Taking numbers from the computer printouts used for that paper a mantle $\varepsilon_{\text {Nd }}$ evolution curve has been calculated. This is shown in Fig. 1 for comparison with Archaean initial ratios and the depleted-

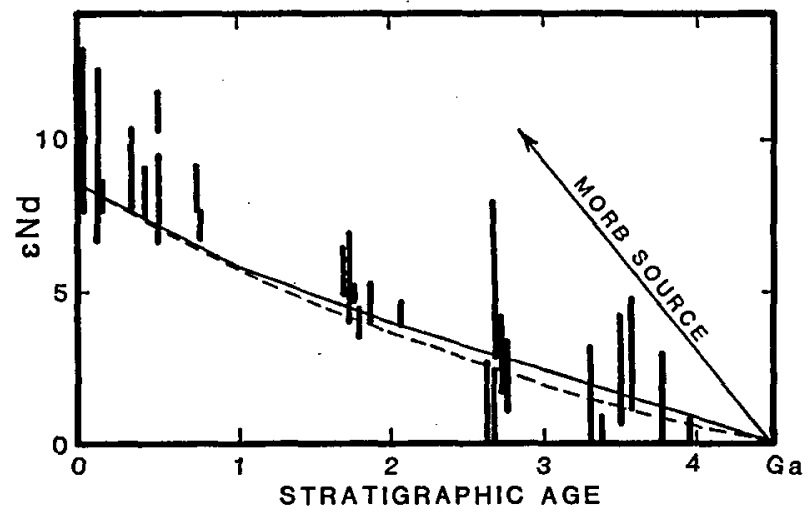

Fig. 1 Plot of $\varepsilon_{\text {Nd }}$ values $v s$ age for ancient igneous rocks (from Smith \& Ludden 1989; Wilson \& Carlson 1989; Bowring et al. 1990) and the depleted mantle growth curve of DePaolo (1981b) (-- ) compared with the shape of the growth curve predicted by the model published by Armstrong (1981) (一). mantle growth curve of DePaolo (1981b). The fit is surprisingly good. In fact, any lesser degree of differentiation of the Earth would be unable to produce a sufficiently depleted and aged mantle. The sigmoidal growth curve, if taken literally, would allow almost no departure of the average mantle $\mathrm{Nd}$ evolution line from the bulk earth (equal to chondrite) reservoir by $3.0 \mathrm{Ga}$.

The recent observations of $\varepsilon_{\mathrm{Nd}}$ values as high as +4.5 in Canadian Early Archaean komatiites (Smith \& Ludden 1989) and +20.1 in Late Archaean ultramafic nodules from Yakutia (McCulloch 1989) require LIL depletion of mantle from the very beginning of Earth history. Even then, with maximum available time, the depletion must be much larger than that implied by the depletedmantle growth curve, and almost twice as large as the average depletion estimated for the MORB source region by DePaolo (1983). DePaolo's average MORB source mantle grows by $6.3 \mathrm{ENd}$ units per $1000 \mathrm{Ma}$, so that by $3.5 \mathrm{Ga}$ any survivor from the initial differentiation in the steady-state model would have an $\varepsilon_{\mathrm{Nd}}$ value of 6.3. Nothing more remarkable than survival of that initial mantle is required to explain Smith and Ludden's observations. By $2.5 \mathrm{Ga}$ any unlikely survivor with MORB-source degree of depletion would have $\varepsilon_{\mathrm{Nd}}$ of 12.6. To produce the high value observed by $\mathrm{McCulloch}$ (1989) for the nodule requires not only survival for a long time but a degree of depletion nearly twice the MORB source value. But that is perhaps not asking too much of a heterogeneous mantle.

Those authors who deny an early fractionation of the Earth into enriched continental crust and depleted mantle are hard pressed to explain the high $\varepsilon_{\text {Nd }}$ values in ancient magma and mantle fragments. Jacobsen (1988, also Jacobsen \& Dymek 1988) offered a model with about $40 \%$ of continental crust by $3.8 \mathrm{Ga}$ to get around this problem. In doing so they moved closer to the steady-state than any previous crustal-growth models. Jacobsen, however, rejected steady-state recycling models by reference to Reymer and Schubert (1984).

It has been frustrating to read statements that the steady-state model cannot or does not explain positive $\varepsilon_{\mathrm{Nd}}$ in Archaean rocks. As a specific example, Menuge (1985) stated, 'The gradual increase of $\varepsilon_{N d}$ with time precludes earlier theories of crust-mantle evolution requiring roughly constant volumes of crust and mantle throughout Earth history (e.g. Armstrong 1968)'. It not only can explain the observation but inherently predicted such an observation before it was made. In 1980 , when the Armstrong (1981) paper was written, the general view was that initial ratios approximately 
followed the chondritic growth curve. This is still true as a first-order description. Only later, with more and better measurements of Proterozoic and Archaean initial ratios, did the depleted-mantle evolution curve become defined and subject to discussion and explanation.

\section{Nd IN SEDIMENTARY ROCKS}

The model Nd age of clastic sedimentary rocks through time is another record of crustal evolution that is now well studied. Jacobsen (1988) has recently compiled published data, much of it his own. Modern sediment has depleted-mantle model ages of 1.4 to $1.8 \mathrm{Ga}$. Going back in time the model ages decrease to a few hundred $\mathrm{Ma}$ or less for the oldest sediments analysed (Jacobsen 1988; Dia et al. 1990).
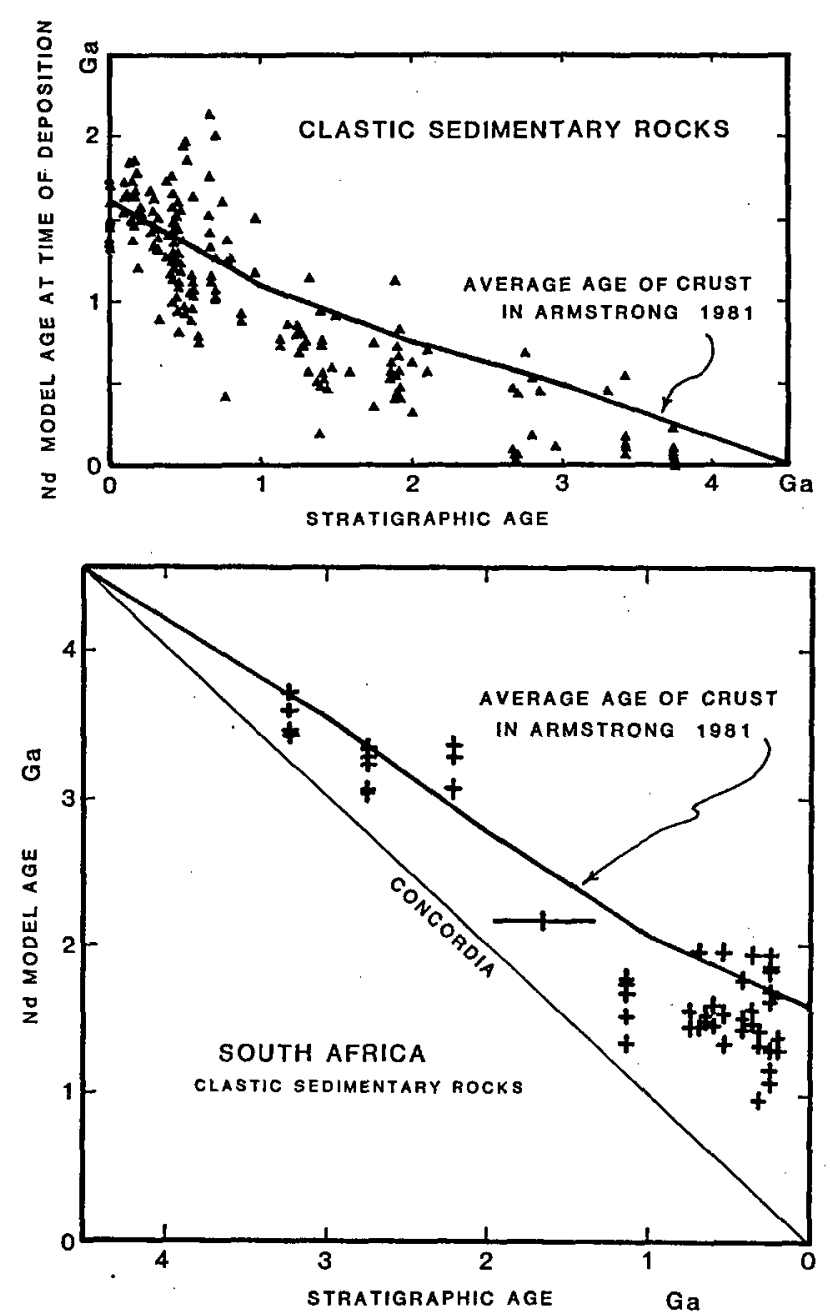

Fig. 2 Comparisons of $\mathrm{Nd}$ isotope data for clastic sediments (a: compilation of Jacobsen 1988; b: data of Dia et al. 1990), expressed as model age, with the average crustal age curve from the model of Armstrong (1981).
Throughout time there is considerable scatter, reflecting the heterogeneity of sediment provenance. Allègre and Rousseau (1984) concluded that the curve reflected decreasing continental crust growth rates through time. Jacobsen (1988) varied both continental growth and recycling rates to achieve a fit to the observations.

The distribution of depleted-mantle model ages of clastic sediment is plotted on Fig. 2 together with a curve of average crustal age for the Armstrong and Hein (1973) and Armstrong (1981) recycling model. The fit is nearly perfect, both in shape and position. Once again the steady-state model is shown to have been inherently predictive, but no one had bothered to look at it! The amount and age of crust in Archaean time specified in the model provide both the complementary reservoir for a depleted mantle and the source of Archaean sediments that conform to actual observations.

Goldstein (1988) has elegantly discussed how the behaviour of $\mathrm{Sr}$ and $\mathrm{Nd}$ may be significantly decoupled during crust-mantle recycling.

\section{HAFNIUM ISOTOPES}

The Hafnium initial ratio evolution for depleted mantle (Patchett et al. 1981) and Hf isotopic composition of ancient sedimentary rocks (Stevenson \& Patchett 1990) could be treated in the same way as has just been done for $\mathrm{Nd}$. The curves are of similar topology because the isotopes of $\mathrm{Nd}$ and $\mathrm{Hf}$ are strongly covariant in their behaviour inside the Earth (White \& Patchett 1984). The sediment data are still limited but there is no evident contradiction between the observations and the curve predicted by the no-growth model (Fig. 3).

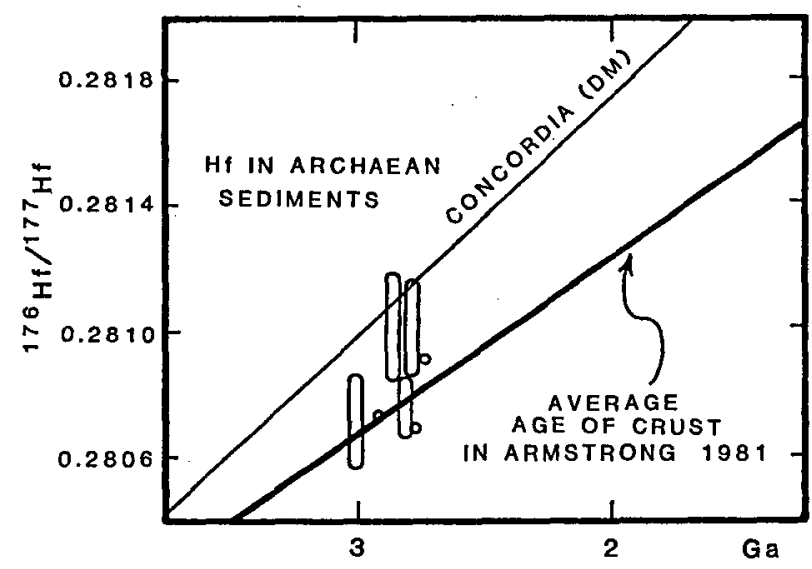

Fig. 3 Comparison of the Armstrong (1981) average crustal age curve with Hf data for zircon from Archaean detrital sediment (Stevenson \& Patchett 1990). 
The no-growth model is, by analogy with the case for $\mathrm{Nd}$, quite capable of explaining the trend of $\mathrm{Hf}$ initial ratios through time, if sediment subduction is occurring at the rate of $1-2 \mathrm{~km}^{3}$ per year. Patchett et al. (1981) admit this but refused to choose that option. It is not the evidence of the isotopes, just their opposition to sediment subduction that leads them to such vigorous opposition to the steady-state model.

[Archaean] shales and zircons from the same locality have similar Nd and Hf model ages. This suggests that there were no great quantities of continental crust in the early Earth ... this argues for a limited extent of pre $3.0 \mathrm{Ga}$ old crust.

They obviously did not understand the workings of the no-growth model. Figures 2 and 3 demonstrate the utter falseness of their statement.

\section{SIMPLE MODELS FOR CRUSTAL EVOLUTION - THE LATE STARTERS}

Many published calculations and discussions of crust evolution are predicated on a delayed beginning for the creation of continental crust (e.g. Lambert 1980, 1981; Patchett et al. 1981; Allègre \& Jaupart 1985; Allègre 1987; Allègre \& Lewin 1989; Turcotte 1989). Any conclusions of such slow starting models are inherently biased against the nogrowth model, and thus are lacking in objectivity. Their conclusions are recycled assumptions and cannot be cited as disproof of the steady-state model. Unfortunately this has often happened.

The simple model of Turcotte (1989) can be taken as an example. He started crustal growth at $4.0 \mathrm{Ga}$, made the growth rate proportional to heat flux out of the earth, and made recycling proportional to the mass of continental crust. There are two flaws in this model. The delayed start is not justified, and the recycling rate should also be proportional to the heat flux. Given those changes his resulting curve would come very, very close to the steady-state model. And one might also ask for a two stage thermal history, with even more energy dissipated during the first billion years. Only by imposing restraints on his calculation has he managed to produce a curve that sort of looks like the one that is currently fashionable.

\section{CONCLUSION}

Except for geochronometry (magnetic reversals, matching of basement provinces across the Atlantic Ocean) the idea that geochemistry played any role in the scientific revolution from fixism through continental drift to plate tectonics has escaped most historians of science (e.g. LeGrand 1988). This is disappointing as there has been a constant interplay of geochemical and tectonic studies, and there is now an intimate intertwining of geochemical and geophysical models for mantle structure and convection. A continental-volume steady-state model, with decreasing crust-mantle recycling rates, proposed in 1968, during the decade of great geophysical discoveries, is not incompatible with geophysical constraints as presently understood (Davies 1984, and other papers to 1990). The only part of 'chemical geodynamics' invented in the 1980 s was the name. The ideas were developed in the 1960 s and earlier.

The idea of steady growth of continental crust survives, as does any myth, by distortion of facts, repetition and self-citation. Its adherents, who still are a majority of geochemists, are reluctant to abandon cherished concepts they grew up with and have vigorously defended during their education and research careers. But I hope that the fallible foundations of this continental growth myth have been sufficiently exposed here for critical appraisal.

The steady-state model has been shown by Armstrong (1981) and again here to be compatible with a wide range of observed isotope data. This time the observed trends of $\mathrm{Nd}$ isotopic initial ratios of mantle derived magma through time and of the $\mathrm{Nd}$ model ages of sedimentary rocks through time have been shown to be predictable by the 1973 and 1981 quantitative models. Whether this will convince a majority of geochemists that the continental volume steady-state model with a declining crust-mantle recycling rate is a viable replacement for the growth myth remains to be seen. A compromise is unnecessary.

\section{ACKNOWLEDGEMENTS}

Radiogenic isotope research and speculation at the University of British Columbia are supported by a Canadian Natural Sciences and Engineering Research Council operating grant to R. L. Armstrong. I thank S. Moorbath, A. Reymer, G. Schubert, J. Veizer, K. Condie, S. R. Taylor, S. McLennan, C. Allègre, J. Patchett, for continuing stimulation, and D. K. Ghosh, G. F. Davies, R. E. Zartman and S. M. McLennan for reviews of the manuscript and softening of some of the sharp edges. Asbestos gloves for the reviewers were provided by the journal editor, I hope. 


\section{REFERENCES}

Albarède F. \& BrouXel M. 1987. The Sm/Nd secular evolution of the continental crust and the depleted mantle. Earth and Planetary Science Letters 82, 25-35.

AllèGRe C. J. 1980. La geodynamique chimique. Livre Jubilaire, Société Géologique France, pp. 87-104.

ALlèGRE C. J. 1982. Chemical geodynamics. Tectonophysics 81, $109-132$

AllÈGRE C. J. 1987. Isotope geodynamics. Earth and Planetary Science Letters 86, 175-203.

ALlĖGR C. J. 1988. The Behavior of the Earth, 272 pp. Harvard University Press, Cambridge, Massachusetts.

Allègre C. J. 1989. Mantle cycling: Processes and time scales. In Hart S. R. and Gülen L. eds. Crust/Mantle Recycling at Convergence Zones, pp. 1-14. Kluwer, Dordrecht.

ALLEGRE C. J. 1990. Cybernetics of the crust/mantle system. Keynote Address, Seventh International Conference on Geochronology, Cosmochronology, and Isotope Geology, Canberra, Australia, 24-29 September 1990.

Allègre C. J. \& Jaupart C. 1985 . Continental tectonics and continental kinetics. Earth and Planetary Science Letters 74, 171-186.

ALLÈGRe C. J. \& LEWIN E. 1989. Chemical structure and history of the Earth: Evidence from global non-linear inversion of isotopic data in a three-box model. Earth and Planetary Science Letters 96, 61-88.

Allekgre C. J. \& Rosseau D. 1984. The growth of the continent through geological time studied by Nd isotope analysis of shales. Earth and Planetary Science Letters 67, 19-34.

AlPher R. G. \& Herman R. C. 1951. The primeval lead isotopic abundances and the age of the Earth's crust. Physical Review 84, $1111-1114$.

ARCulus R. J. 1981. Island arc magmatism in relation to the evolution of the crust and mantle. Tectonophysics $\mathbf{7 5}$, 113-133.

ARMSTRONG R. L. 1968. A model for $\mathrm{Sr}$ and $\mathrm{Pb}$ isotope evolution in a dynamic Earth. Reviews of Geophysics 6, 175-199.

ARMSTRONG R. L. 1971. Isotopic and chemical constraints on models of magma genesis in volcanic arcs. Earth and Planetary Science Letters 12, 137-142.

ARMstrong R. L. 1981. Radiogenic isotopes: The case for crustal recycling on a near-steady-state no-continentalgrowth Earth. Philosophical Transactions of the Royal Society of London A, 301, 443-472.

Armstrong R. L. vs DePaolo D. J. 1981. Comment and reply on Crustal growth and mantle evolution: Inferences from models of element transport and $\mathrm{Nd}$ and $\mathrm{Sr}$ isotopes. Geochimica et Cosmochimica Acta 45, 1251-1254.

ARMSTRONG R. L. \& Hein S. M. 1973. Computer simulation of $\mathrm{Pb}$ and $\mathrm{Sr}$ isotope evolution of the Earth's crust and upper mantle. Geochimica et Cosmochimica Acta 37, 1-18.

Armstrong R. L., PARrish R. R., van Der Heyden P., Scott K., Runkle D. \& Brown R. L. 1991. Early Proterozoic basement exposures in the southern Canadian Cordillera: Core gneiss of Frenchman Cap, Unit I of the Grand Forks Gneiss, and the Vaseaux Formation. Canadian Journal of Earth Sciences (in press)

ARNDT N. T. \& GoldsteIN S. L. 1989. An open boundary between lower continental crust and mantle: Its role in crust formation and crustal recycling. Tectonophysics 161, 201-212.

Aubouin J., von Huene R. et al. 1981. A summary of Deep Sea Drilling Project Leg 67. Shipboard results from the MidAmerica trench transect off Guatemala. Oceanologica Acta, 1981. Proceedings of the 26th International Geological
Congress, Geology of Continental Margins Symposium, pp. 225-232.

Azbel I. YA \& Tolstikmin I. N. 1990. Geodynamics, magmatism and degassing of the Earth. Geochimica et Cosmochimica Acta 54, 139-154.

BARTH T. F. W. 1962. Theoretical Petrology, 416 pp. Wiley, New York

BARTH T. F. W. 1968. The geochemical evolution of continental rocks. In Ahrens L. H. ed. Origin and Distribution of the Elements, pp. 587-597. Pergamon, New York.

Ben Othman D., White W. M. \& Patchett J. 1989. The geochemistry of marine sediments, island arc magma genesis, and crust-mantle recycling. Earth and Planetary Science Letters 94, 1-21.

BICKLE M. J. 1986. Implications of melting for stabilisation of the lithosphere and heat loss in the Archean. Earth and Planetary Science Letters 80, 314-324.

Bloomer S. H. 1983. Distribution and origin of igneous rocks from the landward slopes of the Mariana Trench: Implications for its structure and evolution. Journal of Geophysical Research 8, 7411-7428.

Bowring S. A., Housh T. B. \& IsAChsen C. E. 1990. The Acasta gneisses: Remnant of Earth's early crust. In Jones J. and Newsome H. eds. Origin of the Earth., pp. 319-343. Oxford University Press, New York.

Burke K., Dewey J. F. \& KIDD W. S. F. 1976. Dominance of horizontal movements, arc and microcontinental collisions during the later permobile regime. In Windley $\mathrm{B}$. F. ed. The Early History of the Earth, pp. 113-129. Wiley, New York.

Chase C. G. \& Patchett P. J. 1988. Stored mafic/ultrmafic crust and early Archean mantle depletion. Earth and Planetary Science Letters 91, 66-72.

CHURCH S. E. 1973. Limits of sediment involvement in the genesis of orogenic volcanic rocks. Contributions to Mineralogy and Petrology 39, 17-32.

Clowes R. M., Brandon M. T., Green A. G. et al. 1987. LITHOPROBE - southern Vancouver Island: Cenozoic subduction complex imaged by deep seismic reflections. Canadian Journal of Earth Sciences 24, 31-51.

Cogley J. G. \& Henderson-Sellers A. 1984. The origin and earliest state of the Earth's hydrosphere. Reviews of Geophysics and Space Physics 22, 131-175.

CoNDIE K. C. 1973. Archean magmatism and crustal thickening. Geological Society of America Bulletin 84, 2981-2992.

CoNDIE K. C. 1980 . Origin and early development of the Earth's crust. Precambrian Research 11, 183-197.

CoNDIE K. C. 1984. Archean geotherms and supracrustal assemblages. Tectonophysics 105, 29-41.

Condie K. C. 1985. Secular variation in the composition of basalts: An index to mantle evolution. Journal of Petrology 26, 545-563.

CONDIE K. C. 1986. Origin and early growth rate of continents. Precambrian Research 32, 261-278.

CONDIE K. C. 1989a. Origin of the Earth's crust. Palaeogeography, Palaeoclimatology, Palaeogcology 75, 57-81.

Condie K. C. 1989b. Plate Tectonics and Crustal Evolution, third edition. Pergamon, New York.

CoNDIE K. C. 1990. Growth and accretion of continental crust: Inferences based on Laurentia. Chemical Geology 83, 183-194.

CRISP J. A. 1984. Rates of magma emplacement and volcanic output. Journal of Volcanology and Geothermal Research 20, 177-211.

Crovgh S. T. \& Thompson G. A. 1976. Thermal model of 
continental lithosphere. Journal of Geophysical Research 81, 4857-4862.

DAvies G. F. 1984. Geophysical and isotopic constraints on mantle convection: An interim synthesis. Journal of Geophysical Research 89, 6017-6040.

DAvies G. F. 1990. Mantle plumes, mantle stirring, and hotspot chemistry. Earth and Planetary Science Letters 99, 94-109.

Davies T. A., Hay W. W., Southam J. R. \& Worsley T. R. 1977. Estimates of Cenozoic oceanic sedimentation rates. Science 197, 53-55.

DePaolo D. J. 1980. Crustal growth and mantle evolution: Inferences from models of element transport and $\mathrm{Nd}$ and $\mathrm{Sr}$ isotopes. Geochimica et Cosmochimica Acta 44, 11851196.

DePaolo D. J. 1981a. Crustal growth and mantle evolution: Inferences from models of element transport and $\mathrm{Nd}$ and $\mathrm{Sr}$ isotopes (reply to a comment by R. L. Armstrong). Geochimica et Cosmochimica Acta 45, 1253-1254.

DePaolo D. J. 1981b. Neodymium isotopes in the Colorado Front Range and crust-mantle evolution in the Proterozoic. Nature 291, 193-196.

DePaolo D. J. 1983. The mean life of continents: Estimates of continental recycling rates from $\mathrm{Nd}$ and $\mathrm{Hf}$ isotopic data and implications for mantle structure. Geophysical Research Letters 10, 705-708.

DePaolo D. J. 1988. Neodymium Isotope Chemistry: An Introduction. Springer, New York.

DePaolo D. J. \& Wasserburg G. J. 1979. Petrogenetic mixing models and $\mathrm{Nd}-\mathrm{Sr}$ isotopic patterns. Geochimica et Cosmochimica Acta 43, 615-627.

DEWEY J. F. \& WINDLEY B. F. 1981. Growth and differentiation of the continental crust. Philosophical Transactions of the Royal Society of London A 301, 189-206.

Dia A., Allègre C. J. \& ERlaNk A. J. 1990. The development of continental crust through geological time: The South African case. Earth and Planetary Science Letters 98, 74-89.

Dimrorh E. 1985. A mass balance between Archean and Phanerozoic rates of magma emplacement, crustal growth and erosion: Implications for recycling of the continental crust. Chemical Geology 53, 17-24.

Ellam R. M. \& Hawkesworth C. J. 1988. Elemental and isotopic variations in subduction related basalts: Evidence for a three component model. Contributions to Mineralogy and Petrology 98, 72-80.

FANALE F. P. 1971. A case for catastrophic early degassing of the Earth. Chemical Geology 8, 79-105.

Francis P. \& RuNDle C. C. 1976. Rates of production of the main magma types in the Central Andes. Geological Society of America Bulletin 87, 474-480.

FYFE W. S. 1976. Hydrosphere and continental crust: Growing or shrinking? Geoscience Canada 3, 82-83.

FyFE W. S. 1978. The evolution of the Earth's crust: Modern plate tectonics to ancient hot spot tectonics? Chemical Geology 23, 89-114.

FyFE W. S. 1981. Geosphere interactions and Earth chemistry. American Geophysical Union Geodynamics Series 5, 82-86.

GAler S. J. G. \& O'Nions R. K. 1985. Residence time of thorium, uranium and lead in the mantle with implications for mantle convection. Nature 316, 5778-782.

Gilluly J. 1955. Geologic contrasts between continents and ocean basins. Geological Society of America, Special Paper 62, 7-8.

Goldstern S. L. 1988. Decoupled evolution of $\mathrm{Nd}$ and $\mathrm{Sr}$ iso- topes in the continental crust and the mantle. Nature 336 , 733-738.

GREGOR C. B. 1985. The mass-age distribution of Phanerozoic sediments. In Snelling N. J. ed. The Chronology of the Geological Record. Geological Society Memoir 10, pp. 284-289. Blackwell Scientific Publications, Oxford.

GuRnis M. \& DAvies G. F. 1986. Apparent episodic crustal growth arising from a smoothly evolving mantle. Geology 14, 396-399.

Hargraves R. B. 1981. Precambrian tectonic style: A liberal uniformitarian interpretation. In Kröner A. ed. Precambrian Plate Tectonics, pp. 12-56. Elsevier, Amsterdam.

HART S. R. \& Staudigel H. 1989. Isotopic characterization and identification of recycled components. In Hart S. R. and Gülen L. eds. Crust/Mantle Recycling at Convergence Zones, pp. 15-28. Kluwer, Dordrecht.

Hawkesworth C. \& Ellam R. 1989. Chemical fluxes and wedge replenishment rates along recent destructive plate margins. Geology 17, 46-49.

Hay W. W., Sloan J. L. II \& Wold C. N. 1988. The mass/age distribution and composition of sediments on the ocean floor and the global rate of sediment subduction. Journal of Geophysical Research 93, 14933-14940.

HofFMAN P. F. 1989. Precambrian geology and tectonic history of North America. In Bally A. W. and Palmer A. R. eds. The Geology of North America: An Overview. Geological Society of America, DNAG series A, 447-512.

Hoffman P. F. \& Ranalli G. 1988. Archean ocean flake tectonics. Geophysical Research Letters 15, 1077-1080.

Hofmann A. W., Jochum K. P., Seufert M. \& White W. M. 1986. $\mathrm{Nb}$ and $\mathrm{Pb}$ in oceanic basalts: New constraints on mantle evolution. Earth and Planetary Science Letters 79, 33-45.

Howell D. G. 1989. Tectonics of suspect terranes: Mountain building and continental growth. Chapman and Hall, New York.

Howell D. G. \& MurRay R. W. 1986. A budget for continental growth and denudation. Science 233, 446-449.

Hurley P. M., Hughes H., Faure G., Fairbairn H. W. \& PINSON W. H. JR. 1962. Radiogenic strontium-87 model of continent formation. Journal of Geophysical Research 67, 5315-5334.

HuRley P. M. \& Rand J. R. 1969. Pre-drift continental nuclei. Science 164, 1229-1242.

Hussong D. M. \& UYedA S. 1981. Tectonics in the Mariana Arc: Results of recent studies, including DSDP Leg 60. Oceanologica Acta, 1981. Proceedings of the 26th International Geological Congress, Geology of Continental Margins Symposium, pp. 203-212.

JACOBSEN S. B. 1988. Isotopic constraints on crustal growth and recycling. Earth and Planetary Science Letters 90, 315-329.

Jacobsen S. B. \& DyMeK R. F. 1988. Nd and Sr isotope systematics of clastic metasediments from Isua, West Greenland: Identification of pre-3.8 Ga differentiated crustal components. Journal of Geophysical Research 93, 338-354.

JACOBSEN S. B. \& WASSERBURG G. J. 1979. The mean age of mantle and crustal reservoirs. Journal of Geophysical Research 84, 7411-7427.

JAHN B. \& GRUAU G. 1989. Geochemistry and isotopic characteristics of Archean basalts and komatiites and their inference on early crust-mantle differentiation. In Ashwal L. D. ed. Workshop on the Archean Mantle. Lunar and Planetary Institute Technical Report 89-05, 47-49. 
KARIG D. E. \& KaY R. W. 1981. Fate of sediments on the descending plate at convergent margins. Philosophical Transactions of the Royal Society of London A 301, 233-251.

KAY R. W. 1985. Island arc processes relevant to crustal and mantle evolution. Tectonophysics 112, 1-15.

KAY R. W. \& KAY S. M. 1989. Recycled continental crustal components in Aleutian arc magmas: Implications for crustal growth and mantle heterogeneity. In Hart S. R. and Gülen L. eds. Crust/Mantle Recycling at Convergence Zones, pp. 145-161. Kluwer, Dordrecht.

Kono Y. \& AMaNo M. 1978. Thickening model of the continental lithosphere. Geophysical Journal of the Royal Astronomical Society 54, 405-416.

KRAUSKOPF K. B. 1967. Introduction to Geochemistry McGrawHill, New York.

LAMBERT R. ST J. 1980. The thermal history of the Earth in the Archean. Precambrian Research 11, 199-213.

LAMBERT R. ST J. 1981. Earth tectonics and thermal history: Review and hot-spot model for the Archean. In Kroner A. ed. Precambrian Plate Tectonics, pp. 453-467. Elsevier, Amsterdam.

Langseth M. G., VonHuene R., Nasu N. \& Okada H. 1981. Subsidence of the Japan Trench forearc region of Northern Honshu. Oceanologica Acta, 1981. Proceedings of the 26th International Geological Congress, Geology of Continental Margins Symposium, pp. 173-179.

LEGRAND H. E. 1988. Drifting continents and shifting theories. Cambridge University Press, Cambridge.

Lowman P. D. JR. 1976. Crustal evolution in silicate planets: Implications for the origin of continents. Journal of Geology 84, $1-26$.

MacDonald G. J. F. 1961. Surface heat flow from a differentiated Earth. Journal of Geophysical Research 66, 2489-2493.

Mattioli G. S., Baker M. B., Rutter M. J. \& Stolper E. M. 1989. Upper mantle oxygen fugacity and its relationship to metasomatism. Journal of Geology 97, 521-536.

McCulloch M. T. 1987. Sm-Nd isotopic constraints on the evolution of Precambrian crust in the Australian continent. American Geophysical Union Geodynamics Series 17, 115-130.

McCulloch M. T. 1989. Sm-Nd systematics in eclogite and garnet peridotite nodules from kimberlites: Implications for the early differentiation of the Earth. In Ross J. et al. eds. Proceedings of the 4th International Kimberlite Conference, Perth 1986. Geological Society of Australia, Special Publication 14, pp. 864-876. Blackwell Scientific Publications, Cambridge.

McGovern P. J. \& Schubert G 1989. Thermal evolution of the Earth: Effects of volatile exchange between atmosphere and interior. Earth and Planetary Science Letters 96, 27-37.

McKenzie D. \& Bickle M. J. 1988. The volume and composition of melt generated by extension of the lithosphere. Journal of Petrology 29, 625-679.

MCKeNZIE D. \& O'Nions K. 1990. Melt distribution in the mantle from rare earth element concentrations (abstract). EOS 71, 949.

Mclennan S. M. 1988. Recycling of the continental crust. Pure and Applied Geophysics 128, 683-724.

McLennan S. M. \& TAYLOR S. R. 1981. Role of subducted sediments in island-arc magmatism: Constraints from REE patterns. Earth and Planetary Science Letters 54, 423-430.

Mclennan S. M. \& TAYlor S. R. 1982. Geochemical constraints on the growth of the continental crust. Journal of Geology 90, 347-361.
MClenNan S. M. \& Taylor S. R. 1983. Continental freeboard, sedimentation rates, and growth of continental crust. Nature 306, 169-172.

MENUGE J. F. 1985. Neodymium isotope evidence for the age and origin of the Proterozoic of Telemark, South Norway. In Tobi A. C. and Touret J. L. R. eds. The Deep Proterozoic Crust in the North Atlantic Provinces, pp. 435-448. D. Reidel, Dordrecht.

MiCHAEL P. J. 1988. The concentration, behavior, and storage of $\mathrm{H}_{2} \mathrm{O}$ in the suboceanic upper mantle: Implications for mantle metasomatism. Geochimica et Cosmochimica Acta 52, 556-566.

Moorbath S. 1976. Age and isotope constraints for the evolution of Archean crust. In Windley B. F. ed. The Early History of the Earth, pp. 351-360. Wiley, New York.

Moorbath S. 1977a. Ages, isotopes, and evolution of Precambrian continental crust. Chemical Geology 20, 151-187.

Moorbath S. 1977b. The oldest rocks and the growth of continents. Scientific American 236, 92-104.

MoORBath S. 1978. Age and isotope evidence for the evolution of continental crust. Philosophical Transactions of the Royal Society of London A 288, 401-413.

Moorbath S. 1982. Crustal evolution in the early Precambrian. Revista Brasileira de Geociências 12, 39-44.

MORGaN P. 1989. Thermal factors controlling crustal stabilization. 28th International Geological Congress, Washington, D.C., 1989, Abstracts 3, 333.

Mueller P. A. \& WoOden J. L. 1988. Evidence for Archean subduction and crustal recycling, Wyoming province. Geology 16, 871-874.

MUELler P. A. \& WoOden J. L. 1989. Archean crustal recycling: Implications for isotopic heterogeneity in the mantle. In Ashwal L. D. ed. Workshop on the Archean Mantle. Lunar and Planetary Institute Technical Report 89-05, 63-66.

Neal C. R. \& Taylor L. A. 1989. A negative Ce anomaly in a peridotite xenolith: Evidence for crustal recycling into the mantle or mantle metasomatism. Geochimica et Cosmochimica Acta 53, 1035-1040.

Nelson B. K. \& DePaOlo D. J. 1985. Rapid production of continental crust 1.7 to 1.9 b.y. ago: $\mathrm{Nd}$ isotopic evidence from the basement of the North American mid-continent. Geological Society of America Bulletin 96, 746-754.

NiEUWENRAMP W. 1968. Oceanic and continental basalts in the geochemical cycle. Geologisches Rundschau 57, 362-372.

NisBet E. 1984. The continental and oceanic crust and lithosphere in the Archean: Isostatic, thermal, and tectonic models. Earth and Planetary Science Letters 21, 1426-1441.

NisBet E. 1987. The Young Earth: An Introduction to Archean Geology, $402 \mathrm{pp}$. Allen and Unwin, London.

Nisbet E. G. \& Fowler C. M. R. 1983. Model for Archean plate tectonics. Geology 11, 376-379.

O'Nions R. K. 1990. Melts and other fluids in the development of continental crust (abstract). Seventh International Conference on Geochronology, Cosmochronology, and Isotope Geology, Canberra, Australia, 24-29 September 1990, Abstracts, p. 73.

O'Nions R. K., Evensen N. M. \& Hamilton P. J. 1979. Geochemical modeling of mantle differentiation and crustal growth. Journal of Geophysical Research 84, 6091-6101.

O'Nions R. K. \& HAMiLton P. J. 1981. Isotope and trace element models of crustal evolution. Philosophical Transactions of the Royal Society of London A 301, 473-487.

Oversby V. M. \& Ewart A. 1972. Lead isotopic compositions of Tonga-Kermadec volcanics and their petrogenetic sig- 
nificance. Contributions to Mineralogy and Petrology 37, 181-210.

PARSONS. B. 1981 . The rates of plate creation and consumption. Geophysical Journal of the Royal Astronomical Society 67 , 437-448.

PATchetT P. J. 1983. Importance of the Lu-Hf isotopic system in studies of planetary chronology and chemical evolution. Geochimica et Cosmochimica Acta 47, 81-91.

Patchett P. J. \& Chauvel C. 1984. The mean life of continents is currently not constrained by $\mathrm{Nd}$ and $\mathrm{Hf}$ isotopes. Geophysical Research Letters 11, 151-153.

Patchett P. J., Kouvo O., Hedge C. E. \& Tatsumoto M. 1981. Evolution of continental crust and mantle heterogeneity: Evidence from Hf isotopes. Contributions to Mineralogy and Petrology 78, 279-297.

Patchett P. J., White W. M., Feldman H., Kielinczuk S. \& HofmanN A. W. 1984. Hafnium/rare earth element fractionation in the sedimentary system and crustal recycling into the Earth's mantle. Earth and Planetary Science Letters 69, 365-378.

PATTERSON C. 1964. Characteristics of lead isotope evolution on a continental scale in the Earth. In Craig H., Miller S. L. and Wasserburg G. J. eds. Isotopic and Cosmic Chemistry, pp. 244-268. North-Holland, Amsterdam.

Pearcy L. G., DeBari S. M. \& Sleep N. H. 1990. Mass balance calculations for two sections of island arc crust and implications for the formation of continents. Earth and Planetary Science Letters 96, 427-442.

Peltier W. R. 1989. Models of the thermal history of the Earth (abstract). EOS 70, 1000.

PoldervaART A. 1955. Chemistry of the Earth's crust. Geological Society of America Special Paper 62, 119-144.

Reymer A.\& Schubert G. 1984. Phanerozoic addition rates to the continental crust and crustal growth. Tectonics 3, 63-77.

Reymer A. \& Schubert G. 1987. Phanerozoic and Precambrian crustal growth. American Geophysical Union Geodynamics Series 17, 1-9.

Richter F. M. 1988. A major change in the thermal state of the Earth at the Archean-Proterozoic boundary: Consequences for the nature and preservation of continental lithosphere. Journal of Petrology, Special Lithosphere Issue, pp. 39-52.

RUBEY W. W. 1951. Geologic history of sea water, an attempt to state the problem. Geological Society of America Bulletin 62, $1111-1148$.

RuBEY W. W. 1955. Development of the hydrosphere and atmosphere, with special reference to probable composition of the early atmosphere. Geological Society of America, Special Paper 62, 631-650.

SCHMINCKE H-U. 1981. Volcanic activity away from plate margins. In Smith D. G. ed. The Cambridge Encyclopedia of Earth Sciences, pp. 201-209. Cambridge University Press, Cambridge.

SCHOLL D. W. 1974. Sedimentary sequences in the North Pacific trenches. In Nairn A. E. M. and Stehli F. G. eds. The Geology of Continental Margins, pp. 493-504. Springer, New York.

SCHOLL D. W. \& MARLOW M. S. 1974. Sedimentary sequence in modern Pacific trenches and the deformed circum-Pacific eugeosyncline. Society of Economic Paleontologists and Mineralogists, Special Publication 19, 193-211.

Scholl D. W., von Heune R. \& Dieffenbach H. L. 1990. Rates of sediment subduction and subduction erosion: Implications for growth of terrestrial crust (abstract). EOS 71, 1576.

Schubert G. \& Reymer A. P. S. 1985. Continental volume and freeboard through geological time. Nature 316, 336-339.
Shirey S. B. \& Hanson G. N. 1986. Mantle heterogeneity and crustal recycling in Archean granite-greenstone belts: Evidence from Nd isotopes and trace elements in the Rainy Lake area, Superior Province, Ontario, Canada. Geochimica et Cosmochimica Acta 50, 2631-2651.

SLeEP N. H: \& WINDLey B. F. 1982. Archean plate tectonics: Constraints and inferences. Journal of Geology 90, 363-379.

SMith A. D. \& Ludden J. N. 1989. Nd isotopic evolution of the Precambrian mantle. Earth and Planetary Science Letters 93, 14-22.

SMITH J. V. 1981. The first 800 million years of Earth's history. Philosophical Transactions of the Royal Society of London A 301, 401-422.

SMITH J. V. 1982. Heterogeneous growth of meteorites and planets, especially the Earth and Moon. Journal of Geology 90, $1-48$.

Solomon S. C. 1980. Differentiation of crusts and cores of the terrestrial planets: Lessons for the early Earth? Precambrian Research 10, 177-194.

StaCEY J. S. \& KRAMERS J. D. 1975. Approximation of terrestrial lead isotope evolution by a two-stage model. Earth and Planetary Science Letters 26, 207-221.

Stern C. R. 1989. Tectonic erosion along the western plate margin of South America: Its role in the genesis of some Andean magmas (abstract). EOS 70, 1300.

Stern R. J. \& Ito E. 1983. Trace-element and isotopic constraints on the source of magmas in the active Volcano and Mariana island arcs, western Pacific. Journal of Volcanology and Geothermal Research 18, 461-482.

Stevenson R. K. \& Patchett P. J. 1990. Implications for the evolution of continental crust from $\mathrm{Hf}$ isotope systematics of Archean detrital zircons. Geochimica et Cosmochimica Acta 54, 1683-1697.

Sujkowski Z. L. 1952. Average composition of the sedimentary rocks. American Journal of Science 250, 360-374.

Sun S. S. 1989. Chemical and isotopic compositions of Archean komatiites and siliceous high magnesian basalts: Constraints on early history of Earth and formation of continental crust (abstract). 28th International Geological Congress, Washington, D.C., 1989, Abstracts 3, 196.

TARLING D. H.. ED. 1978. Evolution of the Earth's Crust, 443 pp. Academic Press, London.

TAYLOR S. R. 1967. The origin and growth of continents. Tectonophysics 4, 17-34.

TAYLOR S. R. 1977. Island arc models and the composition of the continental crust. American Geophysical Union, Maurice Ewing Series 1, 325-335.

TAYLOR S. R. 1979. Chemical composition and evolution of the continental crust: The rare earth element evidence. In McElhinny M. W. ed. The Earth: Its Origin, Structure and Evolution, pp. 353-376. Academic Press, London.

TAYLOR S. R. \& MCLenNan S. M. 1981a. The composition and evolution of the continental crust: Rare earth element evidence from sedimentary rocks. Philosophical Transactions of the Royal Society of London A 301, 381-399.

TAYLOR S. R. \& MCLenNaN S. H. 1981b. The rare earth elements in Precambrian sedimentary rocks: Implications for crustal evolution. In Kroner A. ed. Precambrian Plate Tectonics, pp. 527-548. Elsevier, Amsterdam.

Taylor S. R. \& McLennan S. H. 1985. The Continental Crust: Its Composition and Evolution Blackwell Scientific Publications, Oxford.

TAYLOR S. R. \& White A. J. R. 1965. Geochemistry of andesites and the growth of continents. Nature 208, 271-273.

Turcotre D. L. 1989. Dynamics of recycling. In Hart S. R. and 
Gülen L. eds. Crust/Mantle Recycling at Convergence Zones, pp. 245-257. Kluwer, Dordrecht.

UREY H. C. 1954. The origin of the Earth. In Faul H. ed. Nuclear Geology, pp. 355-371. Wiley, New York.

VEIZER J. 1973. Sedimentation in geologic history: Recycling vs evolution or recycling with evolution. Contributions to Mineralogy and Petrology 38, 261-278.

VEIZER J. 1976. Evolution of ores of sedimentary affiliation through geologic history: Relations to the general tendencies in evolution of the crust, hydrosphere, atmosphere, and biosphere. In Wolf K. H. ed. Handbook of Strata-Bound and Strataform Ore Deposits 3, 1-41. Elsevier, Amsterdam.

Velzer J. 1983. Geologic evolution of the Archean-Early Proterozoic Earth. In Schopf J. W. ed. Earth's Earliest Biosphere, Its Origin and Evolution, pp. 240-259. Princeton University Press, Princeton.

VEIZER J. 1988. The evolving exogenic cycle. In Gregor C. B., Garrels R. M., MacKenzie F. T. and Maynard J. B. eds. Chemical Cycles in the Evolution of the Earth, pp. 175-220. Wiley, New York.

VEIZER J. \& JANSEN S. L. 1979. Basement and sedimentary recycling and continental evolution. Journal of Geology 87, 341-370.

VEIZER J. \& JANSEN S. L. 1985. Basement and sedimentary recycling - 2: Time dimension to global tectonics. Journal of Geology 93, 625-643.

von Huene R., Kulm L. D. \& Miller J. 1985. Structure of the frontal part of the Andean convergent margin. Journal of Geophysical Research 90, 5429-5442.

Voshage H., Hofmann A. W., Mazzucchelli M. et al. 1990. Isotopic evidence from the Ivrea Zone for a hybrid lower crust formed by magmatic underplating. Nature 347 , 731-736.

WalcotT C. D. 1894. Geologic time, as indicated by the sedimentary rocks of North America. Proceedings of the American Association for the Advancement of Science 42, 129-169.

WALKER J. C. G. 1977. Origin of the atmosphere: History of the release of volatiles from the solid Earth. In Ponnamperuma C. ed. Chemical Evolution of the Early Precambrian, pp. 1-11. Academic Press, New York.

WARREN P. H. 1989. Growth of the continental crust: A planetary-mantle perspective. Tectonophysics 161, 165-199.
Wasserburg G. J. 1961. Crustal history and the Precambrian time scale. New York Academy of Science Annals 91, 583-594.

WeAVER B. L. \& TARNEY J. 1982. Andesitic magmatism and continental growth. In Thorpe R.S. ed. Andesites: Orogenic Andesites and Related Rocks, pp.639-661. Wiley, New York.

WHITE W. M. 1989. Geochemical evidence for crust-to-mantle recycling in subduction zones. In Hart S. R. and Gülen L. eds. Crust/Mantle Recycling at Convergence Zones, pp. 43-58. Kluwer, Dordrecht.

White W. M. \& Patchetr J. 1984. Hf-Nd-Sr isotopes and incompatible element abundances in island arcs: Implications for magma origins and crust-mantle evolution. Earth and Planetary Science Letters 67, 167-185.

Wilson A. H. \& CaRlson R. W. 1989. A Sm-Nd and Pb isotope study of Archean greenstone belts in the southern Kaapvaal Craton, South Africa. Earth and Planetary Science Letters 96, 89-105.

WiNDLEY B. F. 1977. Timing of continental growth and emergence. Nature 270, 426-428.

WindRIM D. P. \& McCulloch M. T. 1986. Nd and Sr isotopic systematics of central Australian granulites: Chronology of crustal development and constraints on the evolution of lower continental crust. Contributions to Mineralogy and Petrology 94, 289-303.

WISE D. U. 1974. Continental margins, freeboard and the volumes of continents and oceans through time. In Nairn A. E. M. and Stehli F. G. eds. The Geology of Continental Margins, pp. 45-58. Springer, New York.

WOLERY T. J. \& SLEEP N. H. 1988. Interactions of geochemical cycles with the mantle. In Gregor C. B., Garrels R. M., MacKenzie F. T, and Maynard J. B. eds. Chemical Cycles in the Evolution of the Earth, pp. 77-103. Wiley, New York.

Zartman R. E. \& Doe B. R. 1981. Plumbotectonics - the model. Tectonophysics 75, 135-162.

ZarTMAN R. E. \& HaINes S. M. 1988. The plumbotectonic model for $\mathrm{Pb}$ isotopic systematics among major terrestrial reservoirs - A case for bi-directional transport. Geochimica et Cosmochimica Acta 52, 1327-1339.

(Received 23 October 1990; accepted 6 August 1991) 